\title{
Primary Biliary Cirrhosis in Monozygotic and Dizygotic Twins: Genetics, Epigenetics, and Environment
}

\author{
CARLO SELMI,*, ${ }^{\ddagger}$ MARLYN J. MAYO,§ NANCY BACH,\| HIROMI ISHIBASHI,ף PIETRO INVERNIZZI, ${ }^{\ddagger}$ \\ ROBERT G. GISH, ${ }^{\#}$ STUART C. GORDON, ${ }^{* *}$ HARLAN I. WRIGHT, ${ }^{\ddagger}{ }^{\ddagger}$ BRUCE ZWEIBAN,,$\S$ \\ MAURO PODDA, ${ }^{\ddagger}$ and M. ERIC GERSHWIN* \\ *Division of Rheumatology, Allergy, and Clinical Immunology, University of California at Davis, Davis, California; *Division of Internal \\ Medicine, Department of Medicine, Surgery, and Dentistry, University of Milan, Milan, Italy; §Department of Internal Medicine, University of \\ Texas Southwestern, Dallas, Texas; "Department of Liver Diseases, Mt. Sinai University, New York, New York; ${ }^{\top}$ Clinical Research Center, \\ National Nagasaki Medical Center, Nagasaki, Japan; \#Department of Transplant, Sutter California Pacific Medical Center, San Francisco, \\ California; **Division of Gastroenterology and Hepatology, William Beaumont Hospital, Royal Oak, Michigan; 牛Nazih Zuhdi Transplant Institute, \\ Oklahoma City, Oklahoma; and §§Division of Gastroenterology, Southern California Kaiser Permanente Hospital, Panorama City, California
}

Background \& Aims: There is growing evidence that the interplay of genetic susceptibility and environmental factors leads to primary biliary cirrhosis (PBC). In particular, family members of an infected individual have up to a 100 -fold higher risk of developing PBC. Although concordant rates for identical twins in other autoimmune diseases range between $25 \%$ and $50 \%$, there are no such data on PBC. Accordingly, we evaluated the concordance of PBC in a genetically defined population of twin sets and evaluated the clinical characteristics between concordant subjects. Methods: We identified 16 pairs of twins within a 1400 -family cohort followed up by several centers worldwide, evaluated the diagnosis of PBC in all individuals, and determined the zygosity of sets reported as identical by the analysis of 2 highly variable HLA class II regions and 5 short tandem repeats. Results: Eight of 16 sets of twins were monozygotic. In $\mathbf{5}$ of $\mathbf{8}$ monozygotic twin sets, both individuals had PBC (pairwise concordance rate, 0.63). Among the dizygotic twins $(n=8)$, no set was found to be concordant for PBC. Interestingly, the age at onset of disease was similar in $\mathbf{4}$ of $\mathbf{5}$ concordant sets of monozygotic pairs; however, there were differences in natural history and disease severity. Conclusions: The concordance rate of PBC in identical twins is among the highest reported in autoimmunity. However, discordant pairs were identified. The data show not only the role of genetics but also emphasize that either epigenetic factors and/or environment play a critical role.

$\mathrm{P}$ rimary biliary cirrhosis (PBC) is an autoimmune liver disease of unknown origin characterized by chronic inflammation and destruction of intrahepatic bile ducts, eventually leading to liver cirrhosis. ${ }^{1}$ The prevalence of PBC varies in different geographic areas. ${ }^{2,3} \mathrm{Xe}-$ nobiotics have been suggested as environmental factors in loss of tolerance, leading to autoimmunity. ${ }^{4}$ Although a number of genetic factors have been suggested in population and family studies, no definitive genetic association with the development of the disease or its outcome has been found. ${ }^{5}$

Disease concordance rates (CRs) (roughly defined as the proportion of affected pairs concordant for the disease) in monozygotic (MZ) (who are genetically identical but also share the environmental background) and dizygotic (DZ) (who share the environmental factors but not the genetic background) twin pairs are powerful tools to estimate the weight of genetic and environmental factors in the susceptibility to multifactorial diseases. In autoimmune diseases other than PBC, CRs in MZ twins vary widely (Table 1) and, with the exception of celiac disease, have been reported to be $<0.50$ in large cross-sectional studies. Data concerning PBC concordance in $\mathrm{MZ}$ twins are limited to 2 reports. In 1973, the case of twin sisters both with $\mathrm{PBC}$ was reported without ascertaining zygosity. ${ }^{6}$ A more recent report described a pair of identical twins discordant for the disease, ${ }^{7}$ although the monozygosity of the set has been debated ${ }^{8}$ and the healthy twin was found to have low-titer antimitochondrial antibodies (AMA). In this study, we studied the CRs among 8 genetically proven $\mathrm{MZ}$ and $8 \mathrm{DZ}$ twin sets.

Abbreviations used in this paper: AMA, antimitochondrial antibodies; CR, concordance rate; DZ, dizygotic; MZ, monozygotic; PBC, primary biliary cirrhosis; PCR, polymerase chain reaction; STR, short tandem repeat.

(C) 2004 by the American Gastroenterological Association 0016-5085/04/\$30.00 doi:10.1053/S0016-5085(04)00841-8 
Table 1. Evidence of Concordant Occurrence of Autoimmune Diseases in MZ and DZ Twins

\begin{tabular}{|c|c|c|}
\hline & MZ concordance & DZ concordance \\
\hline $\mathrm{PBC}^{7}$ & Discordant pair reported & - \\
\hline $\begin{array}{c}\text { Primary sclerosing } \\
\text { cholangitis } 47\end{array}$ & Concordant pair reported & - \\
\hline $\begin{array}{l}\text { Systemic lupus } \\
\text { erythematosis } 48\end{array}$ & 0.24 & 0.02 \\
\hline $\begin{array}{l}\text { Sjögren's } \\
\text { syndrome } 49\end{array}$ & Concordant pair reported & - \\
\hline $\begin{array}{l}\text { Type } 1 \text { diabetes } \\
\text { mellitus }{ }^{40,50-52}\end{array}$ & $0.21-0.70^{a}$ & $0.00-0.13$ \\
\hline $\begin{array}{l}\text { Rheumatoid } \\
\text { arthritis }^{53-55}\end{array}$ & $0.12-0.15$ & $0.035-0.036$ \\
\hline $\begin{array}{l}\text { Graves' } \\
\text { disease }{ }^{56,57}\end{array}$ & $0.17-0.29$ & $0.00-0.02$ \\
\hline $\begin{array}{l}\text { Multiple } \\
\text { sclerosis } 58,59\end{array}$ & $0.25-0.31^{a}$ & $0.03-4.7$ \\
\hline $\begin{array}{l}\text { Celiac } \\
\text { disease }^{43,60}\end{array}$ & $0.75-0.83$ & 0.11 \\
\hline
\end{tabular}

NOTE. Pairwise concordance rates (ranges) are reported when available.

apairwise concordance rate over 7.5 years or longer.

\section{Patients and Methods}

\section{Subjects}

As part of a long-term effort, our laboratory has collaborated with tertiary referral centers as well as the PBCers, an Internet group of patients. This database includes information on the presence of twins within families that have at least one index case of PBC. At the time this study was initiated, we estimate that there were approximately 1400 families in the database; within this group, we requested information as to whether any sets of twins were present. The investigators involved contacted the twins directly to determine whether they were interested in participating in this study. Through this effort, we identified 16 twin sets in which a diagnosis of PBC was encountered. There were no twins who declined participation in the study. To confirm the diagnosis, a protocol explaining the nature of the study and internationally accepted criteria for the diagnosis of $\mathrm{PBC}^{1}$ was required. There were 8 of 16 twin sets that were believed to be identical. There were 8 additional sets referred to us as being nonidentical, based on either different sex or previously obtained data. To verify the zygosity of those twins referred to us as identical, blood samples were obtained and studied as described below. Clinical data were also obtained. A definite or probable diagnosis of PBC was made when at least 2 of the 3 following criteria were fulfilled: serum AMA positivity at a titer greater than 1:40, elevated serum alkaline phosphatase level for longer than 6 months, and diagnostic liver histology. 9 AMA status was determined by indirect immunofluorescence on Hep-2 cell lines, and a titer greater than 1:40 was considered AMA positive. Liver biopsy was not performed in asymptomatic subjects not presenting other diagnostic criteria. This study protocol respected the ethical guidelines of the 1975 Declaration of Helsinki and subsequent modifications; all patients gave their written consent at the referring center.

\section{DNA and Sera Isolation}

Peripheral blood samples were obtained for DNA isolation in $10-\mathrm{mL}$ tubes containing EDTA. Genomic DNA was obtained from peripheral blood lymphocytes using the Qiagen BloodAmp Maxi Kit (Qiagen, Valencia, CA) and stored at $-20^{\circ} \mathrm{C}$ before use.

\section{Clinical Characteristics of Subjects}

Clinical data were obtained from the referring centers; further, all physicians were asked to reevaluate the diagnosis of $\mathrm{PBC}$ and complete a comprehensive form describing the history and clinical data of each subject. Briefly, 2 of 3 conditions (elevated serum alkaline phosphatase level for longer than 6 months, positivy for serum AMA, or diagnosis by histology) had to be fulfilled to confirm the diagnosis of PBC. Biochemical, serologic, histologic, and ultrasonographic characteristics of patients at the time of blood sampling were also required. Other autoimmune conditions were rigorously evaluated by physicians in each case.

\section{Determination of Zygosity}

The zygosity of 8 twin pairs referred as identical was verified by DNA typing of 2 highly variable HLA class II regions and 5 short tandem repeats (STRs) localized on different chromosomes (listed in Table 2). HLA typing was performed at the University of Texas Southwestern in Dallas using a sequence-specific primer molecular method to identify DRB1 alleles present at an intermediate resolution level. ${ }^{10}$ The presence of DRB3 (DR52), DRB4 (DR53), and DRB5 (DR51) was also determined to be positive or negative. The analysis of STR polymorphisms was performed at the University of California at Davis. In both cases, researchers were blind with

Table 2. Primer Sequences, Size Ranges, and Annealing Temperature Used for the Study of Microsatellite STR Polymorphisms

\begin{tabular}{lcclc}
\hline \multicolumn{1}{c}{ Locus } & $\begin{array}{c}\text { Size range } \\
\text { (base pairs })\end{array}$ & $\begin{array}{c}\text { Annealing } \\
\text { temperature }\left({ }^{\circ} \mathrm{C}\right)\end{array}$ & \multicolumn{1}{c}{ Forward primer } & Reverse primer \\
\hline D4S1647 & $132-156$ & 45 & TATTTCCAACACCCCTGCTA & AAGCAAAGAGGATTGAAAGTG \\
D5S815 & $252-296$ & 45 & TGGTATACTTGTGTAGCAAATTACA & TGCCATGATTGTTAAGTTCC \\
D22S683 & $160-196$ & AACAAAACAAAACAAAACAAACA & GGTGGAATGCCTCATGTAG \\
D7S796 & $162-198$ & 55 & TTTTGGTATTGGCCATCCTA & GAAAGGAACAGAGAGACAGGG \\
D21S1910 & $194-266$ & 55 & TTCTCTGGAATAAACGTGG & CACGGCAAAGTAGTATTTAATG \\
\hline
\end{tabular}


respect to the identity of subjects. Genotypes for STR polymorphisms were determined using polymerase chain reaction (PCR) amplification of $10 \mathrm{ng}$ of genomic DNA in $25-\mu \mathrm{L}$ total volume reactions. The PCR solution included $10 \mathrm{mmol} / \mathrm{L}$ deoxynucleoside triphosphate mix, $25 \mathrm{mmol} / \mathrm{L} \mathrm{MgCl}_{2}$ solution, 10× PCR Gold Buffer, 1 U AmpliTaq Gold polymerase (Applied Biosystems, Foster City, CA), $20 \mu \mathrm{mol} / \mathrm{L}$ Human MapPair Primers (Invitrogen, Carlsbad, CA), and deoxyribonuclease/ribonuclease-free water up to a $25-\mu \mathrm{L}$ volume. Table 2 shows the sequences of the primer sets, the expected size range of the amplified sequence, and the appropriate annealing temperature. Forward primers were labeled with adenosine triphosphate $(\gamma$-33P) (Perkin-Elmer, Boston, MA) using a T4 Polynucleotide Kinase system (Invitrogen). Amplification was performed using a Programmable Thermal Controller (MJ Research Inc., Waltham, MA) under the following conditions: 10 -minute denaturation at $94^{\circ} \mathrm{C}, 9$ cycles of 45 seconds at $94^{\circ} \mathrm{C}, 45$ seconds at $60^{\circ} \mathrm{C}$ to $52^{\circ} \mathrm{C}\left(-1^{\circ} \mathrm{C}\right.$ per cycle $), 60$ seconds at $72^{\circ} \mathrm{C}, 35$ cycles of 45 seconds at $94^{\circ} \mathrm{C}, 45$ seconds at annealing temperature appropriate for each primer (Table 2), and 60 seconds at $72^{\circ} \mathrm{C}$, followed by 7 minutes at $72^{\circ} \mathrm{C}$. On completion of PCR, $1 \mu \mathrm{L}$ of product was taken and added to $15 \mu \mathrm{L}$ of dye and water and heated for 5 minutes at $95^{\circ} \mathrm{C}$. Finally, $3 \mu \mathrm{L}$ of product/dye solution was run onto a $7 \%$ polyacrylamide Bio-Rad Sequencing Gel (Bio-Rad Laboratories, Inc., Hercules, CA) for 3 hours at $60 \mathrm{~W}$ and then transferred to a Molecular Dynamics Phosphor Screen (Amersham Biosciences, Piscataway, NJ). Gel results were analyzed using ImageQuaNT by Molecular Dynamics (Amersham Biosciences). Figure 1 shows the visual results obtained with one set of primers (STR D22S683).

\section{$\mathrm{CR}$ in $\mathrm{MZ}$ and $\mathrm{DZ}$ Twins}

Two types of CR for PBC were assessed for MZ and DZ twins. Pairwise CRs were estimated as described by Emery ${ }^{11}$ and MacGregor ${ }^{12}$ (Pairwise CR $=$ Number of Concordant Pairs/Number of Total Pairs). This CR simply provides the proportion of affected pairs concordant for the disease. To estimate the risk for a twin to be affected given that his or her cotwin has been diagnosed with PBC, we also calculated the proband-wise $\mathrm{CR}$ as follows: Proband-wise $\mathrm{CR}=2 \times$ the Number of Concordant Pairs/ $(2 \times$ the Number of Concordant Pairs + the Number of Discordant Pairs).

\section{Results}

\section{Diagnosis of PBC and Determination of Zygosity}

Based on internationally accepted criteria, ${ }^{1,9}$ we confirmed the diagnosis in 21 of 21 patients previously diagnosed with $\mathrm{PBC}$ by their referring physicians. In the remaining 11 of 11 individuals, we confirmed the absence of $\mathrm{PBC}$, once again as noted by their referring physicians. No doubtful diagnosis of PBC (i.e., only one criterion fulfilled) was encountered. Results obtained by genetic analysis (combining HLA and STR independent typings) confirmed the monozygosity of the 8 twin pairs referred as identical. In our series, therefore, $8 \mathrm{MZ}$ (all female; age range, 38-77 years) and $8 \mathrm{DZ}$ (4 female and 4 male-female pairs; overall age range, $31-60$ years) twin sets were found.

\section{PBC in MZ and DZ Twin Sets}

Among MZ twins (Table 3), PBC was diagnosed in both individuals within 5 pairs of twins; the other 3 sets were discordant for the disease, thus leading to a pairwise CR of 0.63 and a proband-wise CR of 0.77 . When the 8 pairs of $\mathrm{DZ}$ twins were analyzed, none of them presented concordance for occurrence of $\mathrm{PBC}$, leading to null pairwise $\mathrm{CR}$ and proband-wise $\mathrm{CR}$.

In 3 of the 5 concordant MZ twin pairs (Table 4, sets $3-5)$, there were no significant differences in serology, disease stage, or accompanying symptomatology. The age at onset of PBC was similar in 4 of 5 sets of twins; in only one case (set 5), the 2 sisters were diagnosed with PBC within 5 years. In one case (set 2), the twins had significantly different clinical progressions, with one individual (A) presenting signs of stable disease for more than 13 years of follow-up and the other (B) requiring liver transplantation 8 years after the diagnosis of endstage PBC. In another set (set 5), 2 different stages of $\mathrm{PBC}$ were observed at liver histology. We also note that the duration of follow-up in the 3 discordant DZ twins affected by PBC was between 5 and 12 years; the characteristics of the affected twins are presented in Table 5. No clear environmental differences could be identified between affected and nonaffected MZ twins.

\section{Discussion}

A large number of genetic and epidemiologic studies in PBC suggest a variable prevalence of disease in different geographic areas as well as a significant risk for development of disease in first-degree relatives of an affected subject. ${ }^{2,3,13}$ In addition, the relatives of affected diseased individuals often develop PBC within a short time of the first case, suggesting environmental influences. ${ }^{13} \mathrm{~A}$ large number of discrete genetic alleles have been studied in PBC, but there has not been definitive evidence of a specific association. Importantly, the strong association of HLA observed in other autoimmune diseases has not been found in PBC, and often the data are either conflicting or restricted to a specific geographic area. ${ }^{14-26}$ Other polymorphisms have been suggested to confer susceptibility or influence progression of PBC, but again these data are either debated, conflicting, or nonconclusive. ${ }^{27-30}$ 


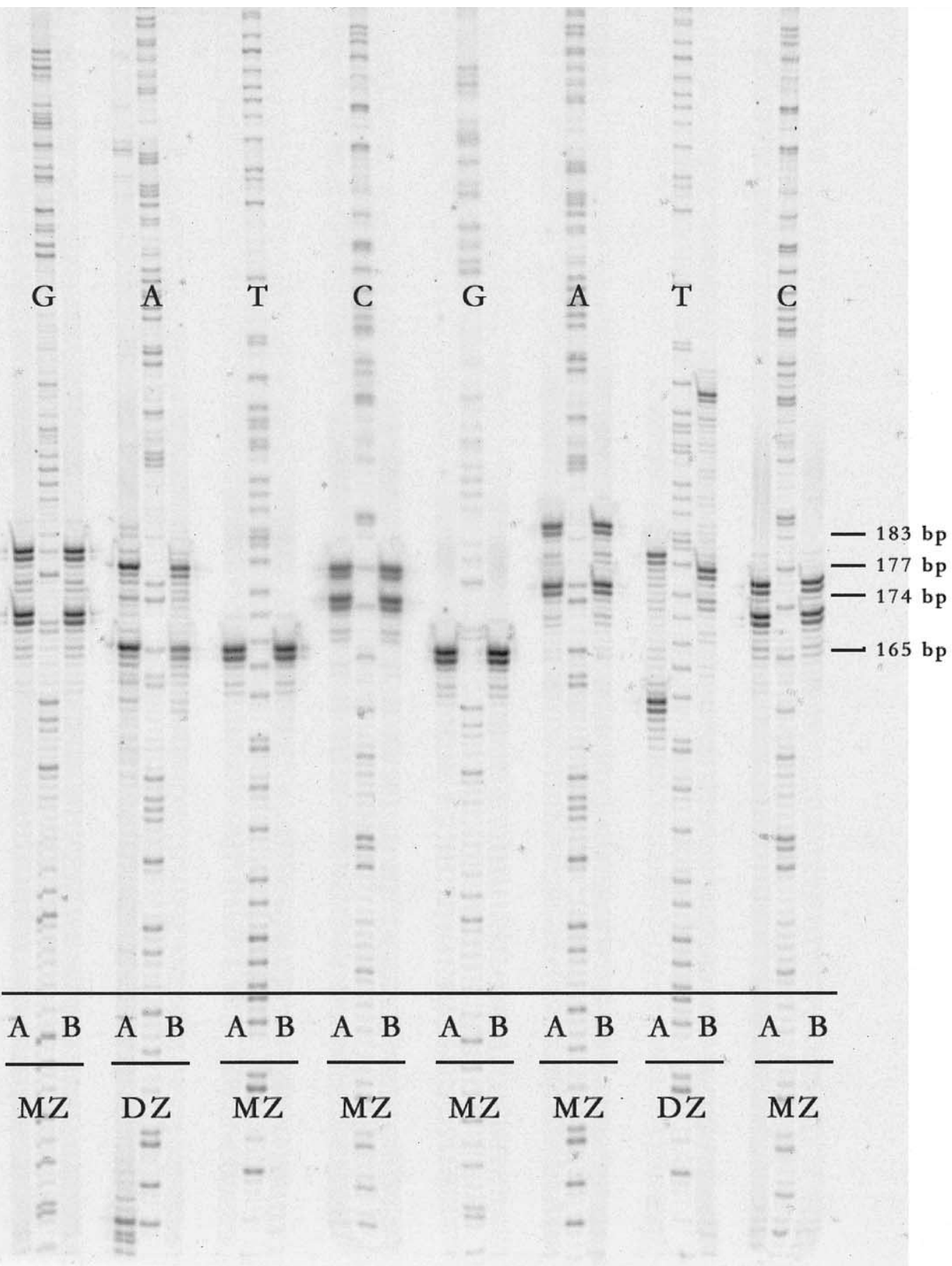

Figure 1. PCR products for the STR polymorphism (range, 160-196 base pairs) at D22S683 are shown for a group of representative MZ and DZ twins.

The frequency of MZ twinning has been relatively constant over the past 5 decades and is estimated to be 4 in 1000 births, whereas DZ rates change over time and are influenced by several factors. ${ }^{31}$ We may therefore infer that the $8 \mathrm{MZ}$ twin sets described herein reflect approximately 2000 patients with PBC, an estimate compatible with the 1400 families we identified. Studies comparing the CR between MZ and DZ twins are pow-
Table 3. Pairwise and Proband-wise CRs for PBC Observed Among MZ and DZ Twins

\begin{tabular}{ccccc}
\hline & Sex & $\begin{array}{c}\text { Concordant } \\
\text { for PBC }\end{array}$ & $\begin{array}{c}\text { Proband-wise } \\
\text { CR }\end{array}$ & $\begin{array}{c}\text { Pairwise } \\
\text { CR }\end{array}$ \\
\hline $\begin{array}{c}\text { MZ twin pairs } \\
(\mathrm{n}=8)\end{array}$ & $8 / 8 \mathrm{~F} / \mathrm{F}$ & $5 / 8$ & 0.63 & 0.77 \\
$\mathrm{DZ}$ twin pairs & $4 / 8 \mathrm{~F} / \mathrm{F}$ & $0 / 4$ & 0 & 0 \\
$(\mathrm{n}=8)$ & $4 / 8 \mathrm{~F} / \mathrm{M}$ & $0 / 4$ & 0 & 0 \\
\hline
\end{tabular}


Table 4. Clinical Characteristics of MZ Twin Pairs Concordant for PBC

\begin{tabular}{|c|c|c|c|c|c|c|c|c|c|c|}
\hline & \multicolumn{2}{|c|}{ Set 1} & \multicolumn{2}{|r|}{ Set 2} & \multicolumn{2}{|c|}{ Set 3} & \multicolumn{2}{|c|}{ Set 4} & \multicolumn{2}{|c|}{ Set 5} \\
\hline & $A$ & B & $A$ & $\mathrm{~B}^{a}$ & $A$ & $\mathrm{~B}$ & $A$ & $\mathrm{~B}$ & $A$ & $\mathrm{~B}$ \\
\hline Ethnicity & \multicolumn{2}{|c|}{ Asian } & \multicolumn{2}{|r|}{ White } & \multicolumn{2}{|c|}{ White } & \multicolumn{2}{|c|}{ White } & \multicolumn{2}{|c|}{ White } \\
\hline Country of residence & \multicolumn{2}{|c|}{ United States } & \multicolumn{2}{|c|}{ United States } & \multicolumn{2}{|c|}{ United States } & \multicolumn{2}{|c|}{ United States } & \multicolumn{2}{|c|}{ Ireland } \\
\hline Birth year & 1925 & & 1952 & & 1964 & & 1946 & & 1953 & \\
\hline Occupation & Housewife & Housewife & Clerical & Consultant & Housewife & Housewife & Nurse & Publisher & Housewife & Housewife \\
\hline $\begin{array}{l}\text { Year of diagnosis } \\
\quad \text { (age }[y r])\end{array}$ & $1990 / 65$ & $1990 / 65$ & $1990 / 38$ & $1988 / 36$ & $1997 / 33$ & $1997 / 33$ & $1995 / 49$ & $1995 / 49$ & $1998 / 55$ & $2003 / 60$ \\
\hline Status & Alive & Alive & Alive & $\begin{array}{l}\text { Orthotopic liver } \\
\text { transplantation } \\
\text { (1996) }\end{array}$ & Alive & Alive & Alive & Alive & Alive & Alive \\
\hline Follow-up ( $y r)$ & 13 & 12 & 13 & 8 & 6 & 6 & 8 & 8 & 6 & 1 \\
\hline Symptoms & Pruritus & Fatigue & None & Liver failure & Fatigue & Fatigue & Fatigue & Fatigue & Pruritus, fatigue & $\begin{array}{l}\text { Pruritus, } \\
\text { fatigue }\end{array}$ \\
\hline $\begin{array}{l}\text { Latest histologic } \\
\text { stage (yr) }\end{array}$ & III (1997) & II (1993) & I (1990) & IV (1996) & III (1999) & II-III (1997) & I-II (2000) & I-II (1995) & I (1998) & II-III (2003) \\
\hline $\begin{array}{l}\text { Endoscopic signs of } \\
\text { portal } \\
\text { hypertension }\end{array}$ & $\begin{array}{l}\text { Mild portal } \\
\text { hypertensive } \\
\text { gastropathy }\end{array}$ & None & None & $\begin{array}{l}\text { Esophageal } \\
\text { varices }\end{array}$ & - & - & None & None & None & Not done \\
\hline $\begin{array}{l}\text { Associated } \\
\text { autoimmune } \\
\text { conditions }\end{array}$ & $\begin{array}{c}\text { Autoimmune } \\
\text { hepatitis }\end{array}$ & Sicca & Sicca & Sicca & None & Sicca & Hypothyroidism & Hypothyroidism & $\begin{array}{l}\text { Raynaud's } \\
\text { syndrome }\end{array}$ & None \\
\hline
\end{tabular}

NOTE. All subjects were female and AMA positive.

${ }^{a}$ All clinical data refer to the condition before orthotopic liver transplantation (1996).

erful tools to evaluate the role of genetic and environmental factors in determining the susceptibility to diseases that appear as multifactorial. However, it should be emphasized that the immune response depends on somatic mutation and such events are stochastic. In other words, there is evidence that the immune response of identical twins may not be identical, as recently described in multiple sclerosis. ${ }^{32}$

Increasing evidence, however, has been provided to challenge the traditional view of $\mathrm{MZ}$ twins as being "identical." Such evidence derives from studies on the effects of intrauterine characteristics as well as on epige- netics. Briefly, in the former case, it has been shown that there may be, during an antenatal infection, a differential involvement of twin fetuses. ${ }^{33}$ Additionally, twins may be different based on the timing of the division of the fertilized egg into 2 separate embryos and ultimately the sharing of the amniotic sac, or chorionic and placental formation. ${ }^{33}$ These specific environmental factors have been shown to be involved in the determination of the phenotype of the fetuses, albeit preserving their identical genome background. Furthermore, epigenetic alterations, indicating differences in the layer of protein and chemicals surrounding the DNA and particularly the

Table 5. Clinical Characteristics of Affected Subjects From MZ Sets Discordant for PBC

\begin{tabular}{|c|c|c|c|}
\hline & \multicolumn{3}{|c|}{ Affected twin from discordant $\mathrm{MZ}$ sets $^{a}$} \\
\hline & $5 \mathrm{~A}$ & $6 \mathrm{~A}$ & $7 \mathrm{~A}$ \\
\hline Sex & Female & Female & Female \\
\hline Ethnicity & White & White & Asian \\
\hline Country of residence & United States & United States & Japan \\
\hline Birth year & 1943 & 1946 & 1942 \\
\hline Occupation & Teacher & Teacher & Housewife \\
\hline Year of diagnosis (age $[y r]$ ) & $1996(53)$ & $1989(43)$ & $1997(55)$ \\
\hline Status & Alive & Alive & Alive \\
\hline Follow-up $(y r)$ & 8 & 12 & 5 \\
\hline AMA & Positive & Positive & Negative \\
\hline Symptoms & None & None & None \\
\hline Latest histologic stage (I-IV) & II (2001) & II-III (1999) & II (1997) \\
\hline Endoscopic signs of portal hypertension & None & Not done & None \\
\hline Associated autoimmune conditions & None & Psoriasis & Type 2 diabetes mellitus \\
\hline
\end{tabular}

aThe unaffected twins from these sets remain asymptomatic. 
sites or levels of DNA methylation, can also interfere with the direct genotype-phenotype correlation. Indeed, epigenetics play a role in cell aging ${ }^{34}$ and neoplasia ${ }^{35}$ and could lead to the discordance observed between MZ twins. For example, based on the surprising data on the variable expression of the sheep callipyge gene, ${ }^{36}$ efforts are now being dedicated to the study of imprinted human genes. Additional factors that might also potentially interfere with the classical model of zygosity in twins are chimerism and mosaicism; these pockets of genetically mismatched cells appear to be relatively frequent in both single and twin births, possibly due to the antenatal sharing of blood supply. ${ }^{37} \mathrm{~A}$ role for chimerism and mosaicism has been suggested in a number of complex diseases, including autoimmune disorders. ${ }^{38}$ Similarly, recently suggested acquired haplotype deficiencies of specific chromosomes ${ }^{39}$ could also be involved in explaining the discordant cases encountered.

In autoimmune conditions other than $\mathrm{PBC}$ (such as systemic lupus erythematosus, type 1 diabetes mellitus, Graves' disease, systemic sclerosis, and rheumatoid arthritis), CRs among MZ twins have been found in crosssectional studies to be generally $<0.50$ (Table 1 ). Some of these studies, however, showed that CR could often be increased by longer periods of follow-up of unaffected individuals. ${ }^{40}$

Our population is the largest group of twins thus far described in PBC. There are, however, several limitations in our data. Firstly, of course, there is potential bias derived from enrollment. We note that this type of recruitment may be responsible for a higher prevalence of females, and that could lead to an overestimation of CR through an overascertainment of concordant pairs. ${ }^{41,42}$ Such biases could be reduced by twin studies based on national or local registries. However, the lack of a reliable register of patients with PBC (as the one recently used for celiac disease ${ }^{43}$ ) and of a sensitive $100 \%$ reliable noninvasive marker of the disease $(5 \%-15 \%$ of patients with PBC lack detectable AMA when tested by indirect immunofluorescence technique ${ }^{1}$ ) militate against this approach. Second, we note that longer observation periods will influence CRs; however, we note the long duration of follow-up of the discordant MZ sets described herein and, therefore, the consistent long-standing status of the unaffected twin. Finally, the data described herein show lower CR among MZ twins compared with our earlier abstract, ${ }^{44}$ thus emphasizing the necessity of a comprehensive determination of zygosity. For example, one set of twins that was previously believed to be $\mathrm{MZ}$ and concordant for PBC turned out to be not twins at all but rather nontwin siblings.
The pairwise and proband-wise CRs for $\mathrm{PBC}$ in $\mathrm{MZ}$ twins described herein (Table 3) were found to be among the highest observed in cross-sectional twin studies on other autoimmune conditions except celiac disease (Table 1). This is a consistent finding with the relative risk factor for development of PBC within a family, which was also found to be the highest among autoimmune disease. ${ }^{13}$ Moreover, we found that both twins within concordant sets were diagnosed with PBC within a short period of time in all but one set (Table 4), although this could be due to the increased awareness related to the diagnosis of $\mathrm{PBC}$ in the twin presenting earlier signs of disease. It is also interesting to note that the clinical and biochemical characteristics were nearly identical in only 2 of 4 concordant MZ pairs. In one set (Table 4; set 2), 2 very different clinical history patterns were encountered. One individual has had a nonprogressing earlystage disease for more than a decade of follow-up, whereas her twin sister underwent orthotopic liver transplantation 8 years after diagnosis of end-stage PBC. No apparent difference in any environmental factor could be identified between the 2 sisters. In another set (set 5), different disease stages were encountered at liver histology, although we emphasize that the liver biopsy specimen showing stage I in patient A was performed 5 years before the histology showing stage II-III was available in patient B. Moreover, 2 slightly different patterns of autoimmunity were noted in another set (Table 4; set 1) in which both sisters presented positive AMA as well as antinuclear antibodies. In one case (set 1, A), histologic analysis showed a PBC/autoimmune hepatitis overlap, whereas only $\mathrm{PBC}$ was found in the other (set 1, B). We also note that 2 of $5 \mathrm{MZ}$ twin pairs (sets 2 and 4) also presented concordant occurrence of sicca syndrome and hypothyroidism as accompanying conditions. We submit that the relatively small number of observations in this study might account for a type II error, possibly responsible for the lack of clinical difference observed in 2 of 5 concordant sets. In diseases as uncommon as PBC, these data still represent a significant number of patients.

The finding of this high degree of concordance seems to suggest that genetics play a major role in the induction of PBC. The possible confounding role for antenatal factors, ${ }^{33}$ epigenetics, ${ }^{45}$ or chimerism and mosaicism, ${ }^{37}$ as previously discussed, could strengthen this assumption. Our data do not rule out the likelihood that environmental factors serve as a trigger, as observed in celiac disease, that presents a high CR in MZ twins and that shares, like PBC, both genetic and environmental etiologic factors. ${ }^{46}$ We suggest that a vigorous study using, for example, inheritance by descent or linkage analysis, is 
critical to determine the genetic basis of PBC. Nonetheless, the size of the PBC cohort represented by the $8 \mathrm{MZ}$ sets described herein is representative, based on the variable reported prevalence rates of $\mathrm{PBC}$, of approximately 5-100 million general population individuals. We encourage an international effort to develop a database on a larger number of twin sets or representative families with more than one member affected to define the genetic basis of PBC.

\section{References}

1. Kaplan MM. Primary biliary cirrhosis. N Engl J Med 1996;335: 1570-1580.

2. Jones DE, Watt FE, Metcalf JV, Bassendine MF, James OF. Familial primary biliary cirrhosis reassessed: a geographicallybased population study. J Hepatol 1999;30:402-407.

3. Parikh-Patel A, Gold E, Mackay IR, Gershwin ME. The geoepidemiology of primary biliary cirrhosis: contrasts and comparisons with the spectrum of autoimmune diseases. Clin Immunol 1999; 91:206-218.

4. Long SA, Quan C, Van de Water J, Nantz MH, Kurth MJ, Barsky D, Colvin ME, Lam KS, Coppel RL, Ansari A, Gershwin ME. Immunoreactivity of organic mimeotopes of the $\mathrm{E} 2$ component of pyruvate dehydrogenase: connecting xenobiotics with primary biliary cirrhosis. J Immunol 2001;167:2956-2963.

5. Tanaka A, Borchers AT, Ishibashi H, Ansari AA, Keen CL, Gershwin ME. Genetic and familial considerations of primary biliary cirrhosis. Am J Gastroenterol 2001;96:8-15.

6. Chohan MR. Primary biliary cirrhosis in twin sisters. Gut 1973; 14:213-214.

7. Kaplan MM, Rabson AR, Lee YM, Williams DL, Montaperto PA. Discordant occurrence of primary biliary cirrhosis in monozygotic twins. N Engl J Med 1994;331:951.

8. Friedrich $\mathrm{C}$. More on primary biliary cirrhosis in monozygotic twins. N Engl J Med 1995;332:336.

9. Metcalf JV, Howel D, James OF, Bhopal R. Primary biliary cirrhosis: epidemiology helping the clinician. BMJ 1996;312:11811182.

10. Olerup 0 , Zetterquist $H$. HLA-DR typing by PCR amplification with sequence-specific primers (PCR-SSP) in 2 hours: an alternative to serological DR typing in clinical practice including donor-recipient matching in cadaveric transplantation. Tissue Antigens 1992;39: 225-235.

11. Emery AEH. Methodology in medical genetics: an introduction to statistical methods. Edinburgh, Scotland: Churchill Livingstone, 1986.

12. MacGregor AJ. Practical approaches to account for biases and confounding in twin data. In: Spector TD, Snieder H, MacGregor AJ, eds. Advances in twin and sib-pair analysis. London, England: Greenwich Medical Media Ltd, 2000:35-52.

13. Tsuji K, Watanabe Y, Van De Water J, Nakanishi T, Kajiyama G, Parikh-Patel A, Coppel R, Gershwin ME. Familial primary biliary cirrhosis in Hiroshima. J Autoimmun 1999;13:171-178.

14. Miyamori $\mathrm{H}$, Kato $\mathrm{Y}$, Kobayashi K, Hattori N. HLA antigens in Japanese patients with primary biliary cirrhosis and autoimmune hepatitis. Digestion 1983;26:213-217.

15. Bassendine MF, Dewar PJ, James OF. HLA-DR antigens in primary biliary cirrhosis: lack of association. Gut 1985;26:625-628.

16. Manns MP, Bremm A, Schneider PM, Notghi A, Gerken G, PragerEberle M, Stradmann-Bellinghausen B, Meyer zum Buschenfelde $\mathrm{KH}$, Rittner C. HLA DRw8 and complement C4 deficiency as risk factors in primary biliary cirrhosis. Gastroenterology 1991;101: 1367-1373.

17. Morling N, Dalhoff K, Fugger L, Georgsen J, Jakobsen B, Ranek L,
Odum N, Svejgaard A. DNA polymorphism of HLA class II genes in primary biliary cirrhosis. Immunogenetics 1992;35:112-116.

18. Maeda T, Onishi S, Saibara T, Iwasaki S, Yamamoto Y. HLA DRw8 and primary biliary cirrhosis. Gastroenterology 1992;103:11181119.

19. Underhill J, Donaldson P, Bray G, Doherty D, Portmann B, Williams $\mathrm{R}$. Susceptibility to primary biliary cirrhosis is associated with the HLA-DR8-DQB1*0402 haplotype. Hepatology 1992;16: 1404-1408.

20. Begovich AB, Klitz W, Moonsamy PV, Van de Water J, Peltz G, Gershwin ME. Genes within the HLA class II region confer both predisposition and resistance to primary biliary cirrhosis. Tissue Antigens 1994;43:71-77.

21. Onishi S, Sakamaki T, Maeda T, Iwamura S, Tomita A, Saibara T, Yamamoto Y. DNA typing of HLA class II genes; DRB1*0803 increases the susceptibility of Japanese to primary biliary cirrhosis. J Hepatol 1994;21:1053-1060.

22. Mella JG, Roschmann E, Maier KP, Volk BA. Association of primary biliary cirrhosis with the allele HLA-DPB1*0301 in a German population. Hepatology 1995;21:398-402.

23. Underhill JA, Donaldson PT, Doherty DG, Manabe K, Williams R. HLA DPB polymorphism in primary sclerosing cholangitis and primary biliary cirrhosis. Hepatology 1995;21:959-962.

24. Donaldson P, Agarwal K, Craggs A, Craig W, James O, Jones D. HLA and interleukin 1 gene polymorphisms in primary biliary cirrhosis: associations with disease progression and disease susceptibility. Gut 2001;48:397-402.

25. Wassmuth R, Depner F, Danielsson A, Hultcrantz R, Loof L, Olson $\mathrm{R}$, Prytz H, Sandberg-Gertzen H, Wallerstedt S, Lindgren S. HLA class II markers and clinical heterogeneity in Swedish patients with primary biliary cirrhosis. Tissue Antigens 2002;59:381387.

26. Invernizzi P, Battezzati PM, Crosignani A, Perego F, Poli F, Morabito A, De Arias AE, Scalamogna M, Zuin M, Podda M. Peculiar HLA polymorphisms in Italian patients with primary biliary cirrhosis. J Hepatol 2003;38:401-406.

27. Agarwal K, Jones DE, Bassendine MF. Genetic susceptibility to primary biliary cirrhosis. Eur J Gastroenterol Hepatol 1999;11: 603-606.

28. Gershwin ME. The natural history of primary biliary cirrhosis: of genes and cooperation. J Hepatol 2001;35:412-415.

29. Selmi C, Zuin M, Meda F, Podda M, Biondi ML, Cecchini F. Common variants of the matrix metalloproteinase-3 (stromelysin) gene promoter in primary biliary cirrhosis. Gastroenterology 2002:122:247-248.

30. Selmi C, Zuin M, Biondi ML, Invernizzi P, Battezzati PM, Bernin M, Meda F, Gershwin ME, Podda M. Genetic variants of endothelial nitric oxide synthase in patients with primary biliary cirrhosis: association with disease severity. J Gastroenterol Hepatol 2003; 18:1150-1155.

31. Bortolus R, Parazzini F, Chatenoud L, Benzi G, Bianchi MM, Marini A. The epidemiology of multiple births. Hum Reprod Update 1999;5:179-187.

32. Haegert DG, Galutira D, Murray TJ, O'Connor P, Gadag V. Identical twins discordant for multiple sclerosis have a shift in their T-cell receptor repertoires. Clin Exp Immunol 2003;134:532537.

33. Gringras $\mathrm{P}$, Chen $\mathrm{W}$. Mechanisms for differences in monozygous twins. Early Hum Dev 2001;64:105-117.

34. Bandyopadhyay D, Medrano EE. The emerging role of epigenetics in cellular and organismal aging. Exp Gerontol 2003;38:12991307.

35. Feinberg AP, Tycko B. Timeline: the history of cancer epigenetics. Nat Rev Cancer 2004;4:1-11.

36. Georges M, Charlier C, Cockett N. The callipyge locus: evidence for the transinteraction of reciprocally imprinted genes. Trends Genet 2003;19:248-252. 
37. Pearson H. Dual identities. Nature 2002;417:10-11.

38. Nelson JL. Microchimerism: incidental byproduct of pregnancy or active participant in human health? Trends Mol Med 2002;8: 109-113.

39. Invernizzi P, Miozzo M, Battezzati PM, Bianchi I, Grati FR, Simoni G, Selmi C, Watnik M, Gershwin ME, Podda M. Frequency of monosomy $\mathrm{X}$ in women with primary biliary cirrhosis. Lancet 2004;363:533-535.

40. Verge CF, Gianani R, Yu L, Pietropaolo M, Smith T, Jackson RA, Soeldner JS, Eisenbarth GS. Late progression to diabetes and evidence for chronic beta-cell autoimmunity in identical twins of patients with type I diabetes. Diabetes 1995;44:1176-1179.

41. Hawkes CH. Twin studies in diabetes mellitus. Diabet Med 1997; 14:347-352.

42. Rowe RE, Leslie RD. Twin studies in insulin dependent diabetes and other autoimmune diseases. Diabetes Metab Rev 1995;11: 121-135.

43. Greco L, Romino R, Coto I, Di Cosmo N, Percopo S, Maglio M, Paparo F, Gasperi V, Limongelli MG, Cotichini R, D'Agate C, Tinto N, Sacchetti L, Tosi R, Stazi MA. The first large population based twin study of coeliac disease. Gut 2002;50:624-628.

44. Selmi C, Mayo MJ, Bach N, Gish RG, Wright HI, Ishibashi H, Gordon SC, Invernizzi P, Seldin MF, Podda M, Gershwin ME. Occurrence of primary biliary cirrhosis in monozygotic twins (abstr). Hepatology 2002;36:387A.

45. Singh SM, Murphy B, O'Reilly R. Epigenetic contributors to the discordance of monozygotic twins. Clin Genet 2002;62:97-103.

46. Sollid LM. Coeliac disease: dissecting a complex inflammatory disorder. Nat Rev Immunol 2002;2:647-655.

47. Quigley EM, LaRusso NF, Ludwig J, MacSween RN, Birnie GG, Watkinson G. Familial occurrence of primary sclerosing cholangitis and ulcerative colitis. Gastroenterology 1983;85:1160-1165.

48. Deapen D, Escalante A, Weinrib L, Horwitz D, Bachman B, RoyBurman P, Walker A, Mack TM. A revised estimate of twin concordance in systemic lupus erythematosus. Arthritis Rheum 1992;35:311-318.

49. Bolstad Al, Haga HJ, Wassmuth R, Jonsson R. Monozygotic twins with primary Sjögren's syndrome. J Rheumatol 2000;27:22642266.

50. Kumar D, Gemayel NS, Deapen D, Kapadia D, Yamashita PH, Lee M, Dwyer JH, Roy-Burman P, Bray GA, Mack TM. North-American twins with IDDM. Genetic, etiological, and clinical significance of disease concordance according to age, zygosity, and the interval after diagnosis in first twin. Diabetes 1993;42:1351-1363.

51. Kyvik KO, Green A, Beck-Nielsen H. Concordance rates of insulin dependent diabetes mellitus: a population based study of young Danish twins. BMJ 1995;311:913-917.
52. Hawa M, Rowe R, Lan MS, Notkins AL, Pozzilli P, Christie MR, Leslie RD. Value of antibodies to islet protein tyrosine phosphatase-like molecule in predicting type 1 diabetes. Diabetes 1997;46:1270-1275.

53. Aho K, Koskenvuo M, Tuominen J, Kaprio J. Occurrence of rheumatoid arthritis in a nationwide series of twins. J Rheumatol 1986;13:899-902.

54. Silman AJ, MacGregor AJ, Thomson W, Holligan S, Carthy D, Farhan A, Ollier WE. Twin concordance rates for rheumatoid arthritis: results from a nationwide study. $\mathrm{Br} J$ Rheumatol 1993; 32:903-907.

55. MacGregor AJ, Snieder H, Rigby AS, Koskenvuo M, Kaprio J, Aho $\mathrm{K}$, Silman AJ. Characterizing the quantitative genetic contribution to rheumatoid arthritis using data from twins. Arthritis Rheum 2000;43:30-37.

56. Ringold DA, Nicoloff JT, Kesler M, Davis H, Hamilton A, Mack T. Further evidence for a strong genetic influence on the development of autoimmune thyroid disease: the California twin study. Thyroid 2002;12:647-653.

57. Brix TH, Kyvik KO, Christensen K, Hegedus L. Evidence for a major role of heredity in Graves' disease: a population-based study of two Danish twin cohorts. J Clin Endocrinol Metab 2001; 86:930-934.

58. Mumford CJ, Wood NW, Kellar-Wood H, Thorpe JW, Miller DH, Compston DA. The British Isles survey of multiple sclerosis in twins. Neurology 1994;44:11-15.

59. Sadovnick AD, Armstrong H, Rice GP, Bulman D, Hashimoto L, Paty DW, Hashimoto SA, Warren S, Hader W, Murray TJ, et al. A population-based study of multiple sclerosis in twins: update. Ann Neurol 1993;33:281-285.

60. Hervonen K, Karell K, Holopainen P, Collin P, Partanen J, Reunala $\mathrm{T}$. Concordance of dermatitis herpetiformis and celiac disease in monozygous twins. J Invest Dermatol 2000;115:990-993.

Received February 10, 2004. Accepted April 29, 2004.

Address requests for reprints to: M. Eric Gershwin, M.D., Division of Rheumatology, Allergy and Clinical Immunology, University of California at Davis, TB 192, Davis, California 95616. e-mail: megershwin@ ucdavis.edu; fax: (530) 752-4669.

Supported by National Institutes of Health grant 39588

The authors thank Joseph Schauer (Division of Rheumatology, Allergy and Clinical Immunology, University of California at Davis, Davis, CA) for STRs typing and Drs. Peter Stastny and Robert Vorhaben (Histocompatibility Laboratory, Transplant Immunology Section, Department of Internal Medicine, University of Texas Southwestern Medical Center, Dallas, TX) for HLA typing. 